\title{
Kationos felületaktív anyag (hexadecilpiridinium-klorid monohidrát) adszorpciója talajokon
}

\author{
${ }^{1}$ BARNA Gyöngyi, ${ }^{2}$ FÖldÉNYI Rita, ${ }^{2}$ TóTh Zoltán, ${ }^{3}$ BALÁzs Réka és ${ }^{1}$ MAKÓ András \\ ${ }^{1}$ MTA ATK Talajtani és Agrokémiai Intézet, Budapest \\ ${ }^{2}$ Pannon Egyetem, MK Föld- és Környezettudományi Intézeti Tanszék, Veszprém \\ ${ }^{3}$ MTA CSFK Földtani és Geokémiai Intézet, Budapest
}

\section{Bevezetés}

A felületaktív anyagok vagy tenzidek kettős karakterü anyagok: egy hidrofil fejrészből és egy hidrofób láncból állnak, ez utóbbi legtöbbször egy hosszú alkillánc (10-20 szén atomból) (PATZKÓ, 1998). Attól függően, hogy milyen a hidrofil rész, ionos és nem ionos csoportra oszthatóak; az ionoson belül pedig megkülönböztethetünk anionos és kationos tenzideket.

Felületaktív anyagok legtöbbször a szennyvizek révén jutnak a környezetbe és a talajba; de számos növényvédő szer, mütrágya is tartalmaz tenzidet (tapadásfokozók, vagy formázó szerek, pl. emulgeáló adalékanyagok).

A felületaktív anyagok adszorpciója/megkötődése a talajon függ: 1. e vegyületek tulajdonságaitól (pl. oldhatóság, kémiai szerkezet, a poláris láncrész hossza), 2. a talaj és a talajoldat összetételétől (szerves anyagok, agyagásványok, vasoxidok mennyisége, az agyagásványok töltéssürüsége stb.) és egyéb jellemzőitől (pl. a kationcsere kapacitás, kémhatás, hőmérséklet) (LAW et al., 1966; MALIK et al., 1972; KUHNT, 1993; XU \& BOYD, 1995; FÖLDÉNYI et al., 2013; MA et al., 2013).

A felületaktív anyagok - típusuktól függően - a talaj számos fizikai, kémiai és mikrobiológiai jellemzőjét megváltoztathatják (DOBOZY et al., 1970; KUHNT, 1993). Befolyásolhatják a beszivárgást, a higroszkóposságot, a porozitást (KUHNT, 1993; ABU-ZREIG et al., 2003), a kapilláris emelést (LAW et al., 1966; DOBOZY et al., 1970), a víztartó-képességet (KARAGUNDUZ et al., 2001), az olajvisszatartóképességet (CSATÁRI et al., 2013), az aggregátum stabilitást (LAW et al., 1966; DoBOzY et al., 1970; PiCCOLO \& MBAGWU, 1989; KUHNT, 1993; MióKOVICS et al., 2011) és a hidraulikus vezetőképességet (ALLRED \& BROWN, 1994; RAO et al., 2006). Meghatározhatják a pH-t, a redox potenciált, az ioncsere kapacitást (KUHNT, 1993), a mikroorganizmusok aktivitását, populációinak összetételét (KUHNT, 1993; BANKS et al., 2014) és a növények fejlődésére és sejtmüködésére is hatással vannak (DoBOzY et al., 1970; KuHNT, 1993).

Postai cím: MAKÓ ANDRÁS, MTA ATK Talajtani és Agrokémiai Intézet,1022 Budapest, Herman Ottó út 15.E-mail: mako_andras@rissac.hu 
A tenzidek egyik különleges alkalmazási területe a talaj- és talajvíztisztítás, ahol a szennyező anyag típusától (szerves vagy szervetlen vegyület) és a közegtől függöen (szilárd vagy folyékony), különböző szerkezetű felületaktív anyagokat szoktak használni (WeSt \& HARWELl, 1992; SABATINI et al., 1996; SHENG et al., 1996; LOWE et al., 1999; GAO et al., 2001; MULLIGAN et al., 2001; RASHID et al., 2004). A talajba juttatva csökkentik a nem vizes fázisú folyadék - non aqueous phase liquid (az NAPL fázis) felületi feszültségét, növelik az oldhatóságát, így az olajos szennyezés könnyebben eltávolítható (RATHERFELDER et al., 2003; HENRY \& SMITH, 2003; RASHID et al., 2004; PARIA, 2008), ugyanakkor elösegíthetik a nehezen oldódó szerves szennyezők megkötődését is (BROWN \& BURRIS, 1996). Mindeközben a felületaktív anyagok maguk is társszennyezőkké válnak.

A vizsgálatainkban alkalmazott kationos felületaktív anyag (hexadecilpiridinium-klorid monohidrát vagy más néven cetilpiridinium-klorid (CPC) megkötődéséről a talajokon viszonylag kevés tanulmány van (LAW et al., 1966). A kutatások zöme a vegyület különféle tiszta ásványi örleményeken történő megkötődését vizsgálja (LAW \& KunZE, 1966; MALIK et al., 1972; SLADE et al., 1978; PATZKÓ \& DÉKÁNY, 1996; BAE et al., 2012; MA et al., 2013).

A CPC-nél intenzívebben tanulmányozott, hozzá nagyon hasonló, közeli „rokon" vegyület, a cetilpiridinium-bromid (CPB). Ezt a tenzidet ugyanis a 60 -as évektől kezdve használták a talajok, illetve üledékek fajlagos felületének gyors meghatározására, így különösen sokat vizsgálták a CPB adszorpciójára ható talaj- és talajásványtani tulajdonságokat (GREENLAND \& QUIRK, 1964; ARINGHIERI \& SEQUI, 1978; MAYER \& ROSSI, 1982). A két vegyületet az adszorpcióban föszerepet játszó azonos kation miatt gyakran együtt jellemzik, mint vegyület-csoportot (cetilpiridinium-halogenidek - CPH) (LAKRA et al., 2013), így a továbbiakban mi is összevontan mutatjuk be a két tenzid talajokon történő adszorpciójának törvényszerüségeit tárgyaló kutatási eredményeket.

A CPH az ásványok külső és belső felületein egy erősen adszorbeált monomolekuláris réteget alakít ki, amelyen egy második, kevésbé erösen kötött réteg is kialakul. A monomolekuláris réteg kialakításához szükséges tenzid mennyiségéből lehet következtetni a felületek nagyságára. Az így meghatározott fajlagos felületek nagyon jól korreláltak a $\mathrm{N}_{2}$ adszorpcióval mért BET-felületekkel a duzzadó agyagásványokat nem, vagy csak kismértékben tartalmazó talajokban. GREENLAND és QUIRK (1964) a belső felületeket is tartalmazó, duzzadó agyagásványok esetében a (külső) BET-felületnél nagyobb fajlagos felületet mértek CPH-val, mint $\mathrm{N}_{2}$-nel, és az eltérések nagyságából következtettek a belső felület méretére. Megállapították azonban, hogy a CPH-val a belső felület némiképp alulbecsült, mivel a töltéshelyek lefedettsége a külső és a belső felületeken eltérő vastagságú. További alulbecslést okozhat a kis rétegtöltés is (egységnyi felületre jutó töltés) (SLADE et al., 1978).

A talajok szervesanyag-tartalma kétféleképpen hathat a $\mathrm{CPH}$ adszorpcióra. Az organominerális komplexumokat kialakító, agyagásványokhoz kötődő, szerves anyagok lefedhetik az agyagásvány felületeket, gátolva a $\mathrm{CPH}$ megkötődést. Ezzel szemben a „szabad” szerves anyag frakció nagy mennyiségben adszorbeálja a tenzidet (BURFORD et al., 1964). 
A felületeken megkötött, kicserélhető kationok minősége is meghatározhatja a $\mathrm{CPH}$ adszorpció mértékét, ugyanis a $\mathrm{Ca}^{2+}, \mathrm{Mg}^{2+}$ vagy a $\mathrm{Fe}^{3+}$ ionok lecserélhetősége lényegesen kisebb (SLADE et al., 1978). Az ásványszemcsék felületén kialakult vasvagy alumínium-oxid bevonatok - kis töltéssürüségük miatt - szintén gátolhatják az összefüggő tenzidborítottság kialakulását (GREENLAND \& QUIRK, 1964). A CPH adszorbeáló negatív töltéshelyek egy részének kialakulása függ a talaj kémhatásától, így a tenzidadszorpcióját befolyásolhatja a talaj pH is (MALIK et al., 1972). A tenzidmolekulák megkötődése nemcsak ionos kölcsönhatások révén történhet, az apoláros szénláncok hosszának növekedésével egyre jelentősebb a van der Waalsféle kötőerök szerepe az adszorpcióban (LAW \& KUNZE, 1966; MALIK et al., 1972).

Jelen kutatásunkban azt vizsgáltuk, hogy mely talajtulajdonságok befolyásolják egy kationos felületaktív anyag megkötődését. Ezek a vizsgálati eredmények alapozzák meg a későbbiekben bemutatandó modellkísérleteket, amelyekben a kationos felületaktív anyag talajfizikai tulajdonságokra gyakorolt hatását határozzuk meg.

\section{Vizsgálati anyag és módszer}

\section{Talajminták}

Vizsgálatainkba a következő talajokat, üledékeket és ásványi örlemény mintákat használtuk(zárójelben a minták kódját tüntettük fel): Karcag, réti szolonyec, B szint (1); Keszthely, Ramann-féle barna erdőtalaj A és B szint (2 és 3); Várvölgy, agyagbemosódásos barna erdőtalajt A és B szint (4 és 5); Salföld, pannon kvarc homok (6); Magyarszombatfa, pszeudoglejes barna erdőtalaj, B szint (7); Paks, lösz (8); Kápolnásnyék, mészlepedékes csernozjom, A szint (9); Mád, Bentonit (10); Zettliz, Kaolin (11); Kisújszállás, réti talaj, A szint (12).

\section{Alapvizsgálatok}

A légszáraz, 2 mm-es szitán átrostált minták alapvizsgálati adatait a vonatkozó magyar szabványok alapján (MSz 0205:1978 és az MSz 0206:1978), szervesanyagtartalmát a Tyurin-féle módszerrel (TYURIN, 1931), a talajminták BET-felületét a minták nitrogén adszorpciójának mérésével (BRUNAUER et al., 1938) határoztuk meg (1. táblázat). A mechanikai összetételt a FAO (ISO 11277: 2009(E)) szabvány szerint mértük.

\section{Röntgen-pordiffrakciós vizsgálatok}

A talajok ásványos összetételét röntgen-pordiffrakcióval (XRD, PHILIPS PW 1710) $45 \mathrm{kV}$ feszültséggel, $35 \mathrm{~mA}$ csőárammal, grafit monokromátort és $\mathrm{Cu} \mathrm{K \alpha}$ sugárzást alkalmazva határoztuk meg. Az agyagásvány-összetétel vizsgálatokat a talajok $2 \mu \mathrm{m}$ alatti szemcseméret frakcióiból végeztük. 
1. táblázat

A talajminták fizikai és kémiai tulajdonságai

\begin{tabular}{|c|c|c|c|c|c|c|c|c|c|c|}
\hline \multirow{2}{*}{$\begin{array}{l}\text { (1) } \\
\text { Minta } \\
\text { kód }\end{array}$} & \multirow{2}{*}{$\begin{array}{l}(2) \\
\mathrm{K}_{\mathrm{A}}\end{array}$} & \multirow{2}{*}{$\begin{array}{l}\text { (3) } \\
\text { hy }_{1}\end{array}$} & $\begin{array}{c}\text { (4) } \\
\text { Agyag } \\
+\mathrm{Fe}\end{array}$ & $\begin{array}{l}(5) \\
\text { Por }\end{array}$ & $\stackrel{(6)}{\text { Homok }}$ & $\begin{array}{c}\text { (7) } \\
\text { Humusz }\end{array}$ & $\mathrm{CaCO}_{3}$ & \multirow[t]{2}{*}{$\begin{array}{c}\mathrm{pH} \\
\left(\mathrm{H}_{2} \mathrm{O}\right)\end{array}$} & $\begin{array}{c}(8) \\
\text { T-érték }\end{array}$ & $\begin{array}{c}\text { (9) } \\
\text { BET- } \\
\text { felület }\end{array}$ \\
\hline & & & \multicolumn{5}{|c|}{$\%$} & & $\begin{array}{l}\text { mgeé } \\
100 \mathrm{~g}^{-1}\end{array}$ & $\mathrm{~m}^{2} \cdot \mathrm{g}^{-1}$ \\
\hline 1 & 90 & 3,90 & 51,09 & 45,90 & 0,88 & 2,00 & 0,13 & 6,92 & 40,85 & 43,0 \\
\hline 2 & 30 & 1,24 & 20,99 & 33,13 & 44,28 & 1,55 & 0,05 & 7,04 & 11,84 & 11,0 \\
\hline 3 & 36 & 1,49 & 22,89 & 33,87 & 42,29 & 0,94 & 0,00 & 6,83 & 12,38 & 19,0 \\
\hline 4 & 29 & 1,07 & 15,27 & 29,35 & 54,05 & 1,33 & 0,00 & 6,59 & 10,36 & 10,0 \\
\hline 5 & 38 & 1,58 & 22,25 & 26,56 & 50,49 & 0,70 & 0,00 & 6,64 & 12,78 & 20,0 \\
\hline 6 & 29 & 0,07 & 0,98 & 0,40 & 98,60 & 0,00 & 0,02 & 7,44 & 0,70 & 1,0 \\
\hline 7 & 59 & 2,22 & 38,96 & 25,93 & 34,61 & 0,49 & 0,00 & 5,74 & 16,78 & 30,0 \\
\hline 8 & 38 & 1,02 & 16,08 & 46,00 & 9,25 & 0,63 & 28,04 & 8,17 & 19,74 & 12,0 \\
\hline 9 & 46 & 2,25 & 27,60 & 51,68 & 7,50 & 3,70 & 9,52 & 7,83 & 30,25 & 14,0 \\
\hline 10 & 143 & 4,50 & 64,72 & 29,44 & 4,94 & 0,00 & 0,90 & 9,63 & 36,35 & 48,5 \\
\hline 11 & 127 & 0,84 & 49,83 & 48,98 & 0,09 & 0,00 & 1,10 & 8,69 & 14,54 & 17,5 \\
\hline 12 & 74 & 4,49 & 55,01 & 41,19 & 1,05 & 2,76 & 1,10 & 7,51 & 35,69 & 47,0 \\
\hline
\end{tabular}

A $2 \mu \mathrm{m}$ alatti frakciót az elózetesen desztillált vízben többször átmosott, diszpergált, majd porított mintákból ülepítéssel állítottuk elő. A duzzadó agyagásványok meghatározásához minden mintát etilén-glikollal telítettük. Elvégeztük az összes minta hökezelését is 350 , illetve $550{ }^{\circ} \mathrm{C}$-on, a kaolinit és a klorit elkülönítése, valamint a közberétegzett agyagásványok meghatározása érdekében. A domináns agyagásvány alapján csoportosítottuk a mintákat.

\section{Adszorpciós vizsgálatok}

Az általunk használt kationos felületaktív anyagot, a hexadecilpiridinium-klorid monohidrátot (Sigma-Aldrich Kft.) föként a gyógyszer- és a kozmetikai iparban alkalmazzák jó baktérium- és gombaölő tulajdonságai miatt (HRENOVIC et al., 2008). Szerkezeti képlete és egyéb jellemzői a 2. táblázatban láthatók.

$$
\text { 2. táblázat }
$$

A hexadecilpiridinium-klorid monohidrát fontosabb tulajdonságai

\begin{tabular}{|l|c|c|}
\hline \multicolumn{1}{|c|}{ Tulajdonságok } & Érték & Szerkezeti képlet \\
\hline a) Összegképlet & $\mathrm{C}_{21} \mathrm{H}_{38} \mathrm{ClN}^{*} \mathrm{H}_{2} \mathrm{O}$ \\
b) Molekulatömeg, $\mathrm{g} \cdot \mathrm{mol}^{-1}$ & 358,01 \\
c) Oldhatóság vízben, $\mathrm{g} \cdot \mathrm{dm}^{-3}\left(20^{\circ} \mathrm{C}\right)$ & 50 \\
d) Sürüség, $\mathrm{g} \cdot \mathrm{cm}^{-3}$ & 0,37 & $5,0-5,4$
\end{tabular}


A talajminták felületaktív anyaggal történő kezelését sztatikus egyensúlyi kísérletek (static equilibrium experiments) eredményei alapján (FöLDÉNYI et al., 2013), az ún. „elárasztásos módszerrel” végeztük. A mintákhoz olyan mennyiségű tenzidet adtunk, amely mellett feltételeztük, hogy a talajszemcsék felületén monomolekuláris tenzidborítottság alakul ki, ezáltal azok teljesen hidrofóbbá válnak. Ezt a borítottsági értéket a tenzidadszorpciós izotermák segítségével határoztuk meg. Az adszorpciós izotermák felvétele során $5 \mathrm{~g}$ analitikai pontossággal bemért szárított adszorbenshez $5-5 \mathrm{~cm}^{3}$ desztillált vizet adtunk, majd az előkészített mintákat 24 óráig duzzadni hagytuk. Ezt követően a mintákra $45 \mathrm{~cm}^{3}$ adott koncentrációjú tenzidoldatot mértünk. A koncentrációtartományt $1-100 \quad \mathrm{mmol} \cdot \mathrm{cm}^{-3}$ tenzidtartalomra határoztuk meg, amelyet az adszorbensek különböző tulajdonságait figyelembe véve (kationcserélö-képesség, humuszanyag-tartalom) az izoterma $\left(20^{\circ} \mathrm{C}\right)$ első lépcsőjéhez közelítettük. A mérési sorozatokban az egyes koncentrációknak megfelelően három párhuzamos mintával dolgoztunk. Az így előkészített mintákat Varian Cary 50 UV-VIS spektrofotométerrel elemeztük $\lambda=259 \mathrm{~nm}$-en, a mérés (lineáris) tartománya $2,89 \cdot 10^{-5}-6,98 \cdot 10^{-4} \mathrm{~mol} \cdot \mathrm{dm}^{-3}$ volt. A mérés relatív hibája $1-3 \%$, kimutatási határa $10^{-4}-10^{-6} \mathrm{~mol} \cdot \mathrm{dm}^{-3}$. A talajminták által adszorbeált fajlagos CPC mennyiségét az (1) egyenlet segítségével számítottuk:

$$
\mathrm{q}=\frac{\left(\mathrm{c}_{0}-\mathrm{c}_{\mathrm{e}}\right) \cdot \mathrm{V}}{\mathrm{m}}
$$

ahol: $q$ a fajlagos adszorbeált anyagmennyiség, $\mathrm{mol} \cdot \mathrm{g}^{-1}$ adszorbens; $c_{0}$ az adszorptívum kezdeti koncentrációja, mol $\cdot \mathrm{cm}^{-3} ; c_{e}$ az adszorptívum egyensúlyi koncentrációja, mol $\cdot \mathrm{cm}^{-3} ; V$ az oldat térfogata, $\mathrm{cm}^{3} ; m$ az adszorbens tömege, $\mathrm{g}$.

\section{Statisztikai vizsgálatok}

A talajminták fajlagos tenzidadszorpcióját varianciaanalízissel (SPSS 13.1/Oneway ANOVA) hasonlítottuk össze. A statisztikai próbák alkalmazása előtt teszteltük az összehasonlítandó csoportok szóráseloszlását (Levene-próba). Amennyiben a csoportok szórása szignifikánsan különbözött, a hagyományos Duncan teszt helyett a Dunett T3 tesztet használtuk a középértékek különbözőségének elbírálásakor. A statisztikai próbák eredményeit nagybetüs jelölésekkel adtuk meg (a különböző betüjelzések az egymástól - 5\%-os szignifikancia szinten - eltérő csoportokat jelölik).

A szakirodalmi előzmények alapján a tenzidadszorpciót meghatározó legfontosabbnak vélt talajtulajdonságok és a minták felületén monomolekulárisan megkötött tenzid mennyisége közötti kapcsolat erősségének vizsgálatára korrelációs számításokat végeztünk (SPSS/Correlate/Bivariate/Pearson). A korrelációs vizsgálatok alapján a tenzidadszorpciót befolyásoló (egymással szoros kapcsolatot nem mutató) talajparaméterek bevonásával többváltozós regresz-szióanalízist végeztünk (SPSS/Analyse/Regression/Linear/Backward elimination) abból a célból, hogy a megvizsgáljuk a talajtulajdonságok - esetleges - együttes hatását a CPC adszorpcióra. 


\section{Vizsgálati eredmények és következtetések}

\section{Röntgen-diffrakciós mérések}

A teljes minták ásványos összetételét a 3. táblázatban mutatjuk be. Az ásványtani eredmények alapján - az uralkodó- és a talajtulajdonságokat befolyásoló agyagásványok szerint - a vizsgált talajok hat csoportba sorolhatóak. A csoportokat az adszorpciós jellegek alapján a kedvezőbbtől a kevésbé kedvezőbbig tüntettük fel. Az agyagásványos tulajdonságokat az egyéb talajalkotók (szerves anyagok, vasoxihidroxidok) módosíthatják, ezek a csoportosításban kiemelésre kerültek.

\section{3. táblázat}

A minták félmennyiségi ásványos összetétele, \%

\begin{tabular}{|c|c|c|c|c|c|c|c|c|c|}
\hline $\begin{array}{c}(1) \\
\text { Minta } \\
\text { kód }\end{array}$ & $\begin{array}{c}\text { Duzzadó } \\
\text { agyag- } \\
\text { ásványok }\end{array}$ & $\begin{array}{c}(3) \\
\text { Illit/ } \\
\text { Csillám }\end{array}$ & $\begin{array}{c}(4) \\
\text { Klorit/ } \\
\text { Kaolinit }\end{array}$ & $\begin{array}{c}(5) \\
\text { Kvarc }\end{array}$ & $\begin{array}{c}(6) \\
\text { K- } \\
\text { földpát }\end{array}$ & $\begin{array}{c}(7) \\
\text { Plagio- } \\
\text { klász }\end{array}$ & $\begin{array}{c}(8) \\
\text { Kalcit }\end{array}$ & $\begin{array}{c}(9) \\
\text { Dolomit }\end{array}$ & $\begin{array}{c}(10) \\
\text { Goethit }\end{array}$ \\
\hline 1 & 4 & 15 & 5 & 62 & 2 & 12 & 0 & 0 & 0 \\
2 & 2 & 10 & 4 & 70 & 2 & 12 & 0 & 0 & 0 \\
3 & 2 & 10 & 5 & 68 & 2 & 12 & 0 & 0 & 2 \\
4 & 2 & 3 & 2 & 76 & 7 & 10 & 0 & 0 & 0 \\
5 & 5 & 5 & 3 & 70 & 4 & 10 & 0 & 0 & 3 \\
7 & 5 & 8 & 6 & 62 & 3 & 6 & 0 & 0 & 10 \\
8 & 5 & 10 & 6 & 40 & 3 & 10 & 13 & 13 & 5 \\
9 & 2 & 7 & 6 & 58 & 5 & 10 & 10 & 2 & 0 \\
10 & 30 & 0 & 10 & 0 & 10 & 30 & 0 & 0 & 0 \\
11 & 0 & 5 & 90 & 5 & 0 & 0 & 0 & 0 & 0 \\
12 & 4 & 20 & 4 & 60 & 2 & 10 & 0 & 0 & 0 \\
\hline
\end{tabular}

1. Szmektites (kis rétegtöltésü montmorillonitos) talajok. A karcagi (1.) és a kisújszállási (12.) minták döntően montmorillonitos jellegủek. A nagy agyagásvány-tartalom mellett a talaj agyagásványos karaktere nagymértékben befolyásolja a szorpciós, folyadékvezetési és -visszatartási folyamatokat. A talaj agyagásványai közül a talajszmektiteket jellemzi általában a legnagyobb adszorpciós kapacitás és duzzadóképesség. Ezen talajok tulajdonságai - az ásványi őrlemény minták közül - a bentonithoz (10) hasonlíthatóak; lényeges különbség azonban a talajminták viszonylag nagy humusztartalma (2,00 és $2,76 \%)$.

2. Vermikulitos talajok. A magyarszombatfai talaj (7.) az előző csoporthoz hasonlóan kedvező szorpciós tulajdonságú. A vermikulit rétegközi duzzadása kisebb a szmektitekhez képest. A minta agyagásványos tulajdonságait azonban az agyagszemcséket összetapasztó vas-oxihidroxid (goethit, ferrihidrit) bevonatok számottevően módosíthatják.

3. Szmektitet is tartalmazó illites minták. A paksi lösz (8.) nagy karbonáttartalmú (kalcit és dolomit). A kisebb goethit mennyiség mellett illitet és szmektitet is tartalmaz. 
4. Klorit/vermikulit tartalmú talajok. A keszthelyi (2. és 3.) és a várvölgyi (4. és 5.) erdőtalajokból származó mintákat klorit közberétegződésủ vermikulit jellemzi. A kevert szerkezet az előző csoportokhoz képest kisebb adszorpciós és vízmegkötő kapacitást jelent. A klorit/vermikulit mellett jellemző a kaolinit, így ezek a minták az ásványi őrlemény minták közül a kaolinnal (11.) vethetök öszsze.

5. Illit és klorit tartalmú talajok. A kápolnásnyéki csernozjomban (9.) a duzzadó agyagásványok hiánya lassú talajfolyamatokra (agyagosodás) utal. A mintában a szorpciós tulajdonságokat a szerves anyagok határozzák meg (humusztartalom: $3,7 \%)$

6. Nagy kvarctartalmú minták. Külön csoportba sorolható a salföldi pannon homok (6.) minta, mely agyagásványt egyáltalán nem tartalmaz, szinte kizárólag kvarcból áll.

\section{CPC adszorpciós izotermák értékelése}

A becsült monomolekuláris $\mathrm{CPC}$ borítottság kialakításához szükséges tenzidmennyiségek meghatározásának módját a kisújszállási réti talaj (12.) példáján mutatjuk be. Az 1. ábra szemlélteti a talaj által - a CPC oldat koncentrációjának függvényében $-20^{\circ} \mathrm{C}$-on adszorbeált tenzidmennyiségeket, illetve a mért értékekre illesztett Langmuir-típusú izotermát.

Az illesztett görbe telítődő jelleget mutat, amelynek első szakasza - a Giles-féle csoportosítás (GILES et al., 1960) szerint - a nagy affinitású H-típusra utal. A görbe alapján azonban csak a maximális adszorbeált mennyiséget (bimolekulás réteg kialakulása) tudjuk behatárolni, ami a $\mathrm{CPC}$, mint kationos tenzid esetében a micellák több rétegủ megkötődésével jár.

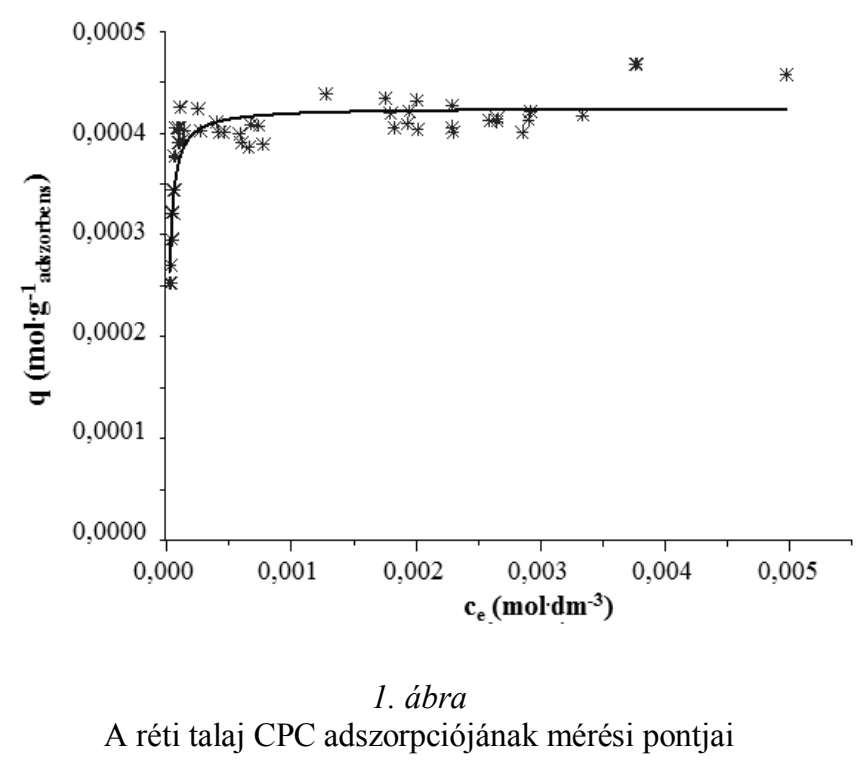




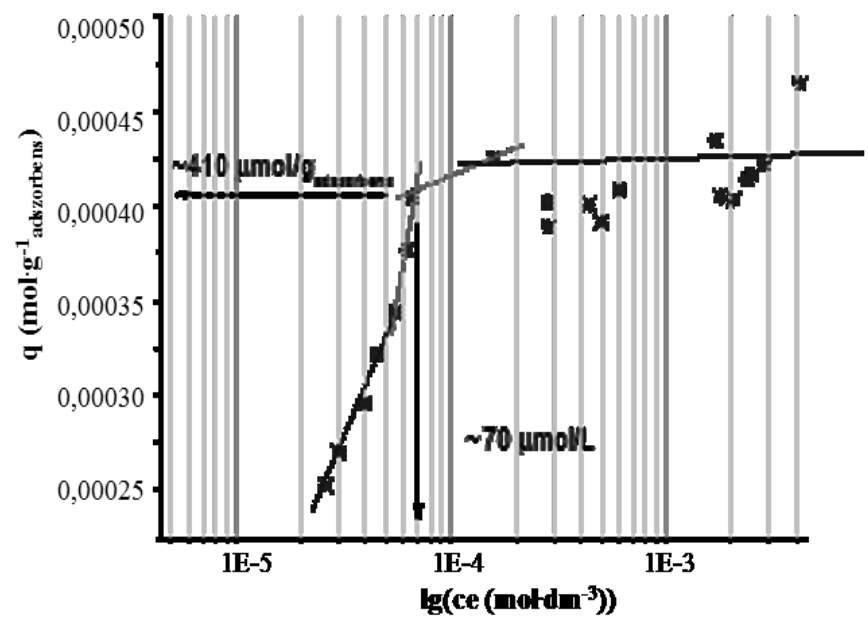

2. ábra

Monomolekuláris $\mathrm{CPC}$ réteg meghatározása réti talaj esetében

A monomolekuláris (hidrofóbizáló) réteg az izoterma első, nagy affinitású szakaszában alakul ki. Ennek meghatározásához a fajlagos adszorbeált mennyiségeket célszerủ az egyensúlyi koncentráció (tízes alapú) logaritmusának függvényében ábrázolni (2. ábra). A H-típusú izoterma kezdeti szakaszának változásait ugyanis a normál skálán nemérzékelhetőek. A logaritmizálást követően az izotermán négy különálló szakasz különíthető el (FAN et al., 1997; ATKIN et al., 2003) (3. ábra).

Az I. szakaszban az adszorpciót elsősorban az elektrosztatikus kölcsönhatások befolyásolják. A molekulák, csekély számuk miatt elszórtan helyezkednek el a felületen, így a közöttük lévő kölcsönhatás elhanyagolható.

A II. szakaszban az egyre növekvő számú tenzidmolekulák orientációra kényszerítik a szomszédos megkötődött molekulákat, aminek köszönhetően közel egységes - a tenzidmolekuláknak köszönhetően - töltés semleges hidrofób felület alakul ki. Ebben az izoterma szakaszban, bár jelen vannak már különféle kölcsönhatások az adszorbeált anyag molekulái között, a molekulák még elsősorban monomerek formájában fordulnak elö.

A III. szakaszban a folyadékfázisban jelenlévő nagy mennyiségü tenzidmolekulák kölcsönhatásba lépnek a már adszorbeálódott molekulákkal, aminek következtében adszorbeálódott micellák alakulnak ki a felületen. Az ellentétes orientációnak köszönhetően a felületen ebben a szakaszban elkezd kialakulni a tenzidre jellemző $(+)$ töltés egyenletes eloszlása.

A IV. szakaszban ez az ellentétes irányítottsággal adszorbeált tenzidréteg is kialakul, amelyet az izoterma telítési szakasza jelez.

A szakirodalom alapján tehát a hidrofób tulajdonságokat biztosító monomolekuláris tenzidborítottság (hidrofób felület) a II. és III. szakasz metszeténél olvasható le (FAN et al., 1997). 


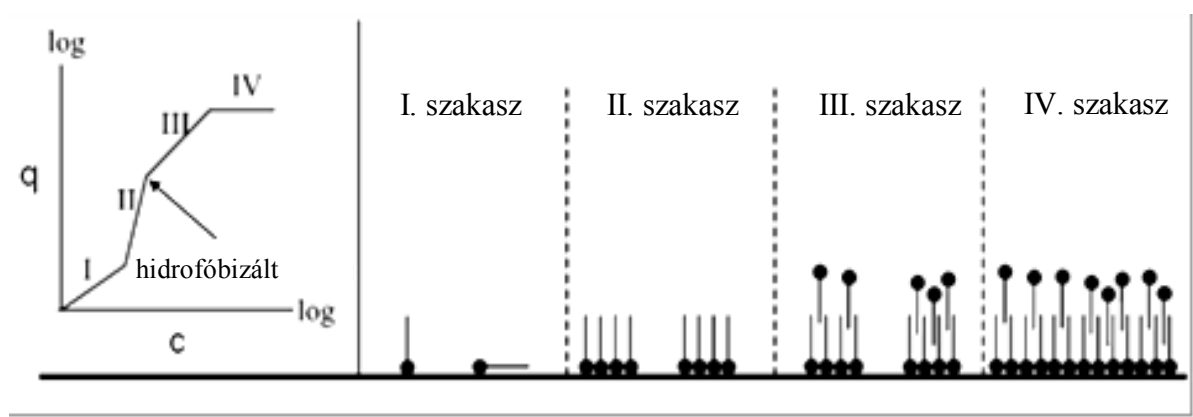

3. ábra

Ionos tenzidek irányított adszorpciója (FAN et al., 1997 nyomán)

A leírt példa szerint meghatároztuk a vizsgált talajok (adszorbensek) hidrofóbizálásához szükséges fajlagos tenzidmennyiségeket (4. ábra). Az ábrán bemutatott tenzidadszorpciós értékeket elemezve megállapítottuk, hogy az egyes minták monomolekuláris rétegborítottságához szükséges tenzidmennyiségek mintánként általában szignifikánsan eltérőek. A fajlagos CPC-mennyiséget a nagy agyagtartalmú, szmektites minták esetében (1., 10. és 12) találtuk a legnagyobbnak, a salföldi homokmintánál pedig a legkisebbnek.

A továbbiakban azt vizsgáltuk, hogy a talajminták mely tulajdonságai állnak kapcsolatban a monomolekuláris telítettségnél adszorbeált fajlagos tenzidmennyiségekkel (később ld. „tenzidadszorpció”). Számítottuk a Pearson-féle korrelációs együtthatókat (SPSS Analyse/Correlate/ Bivariate) (4. táblázat).

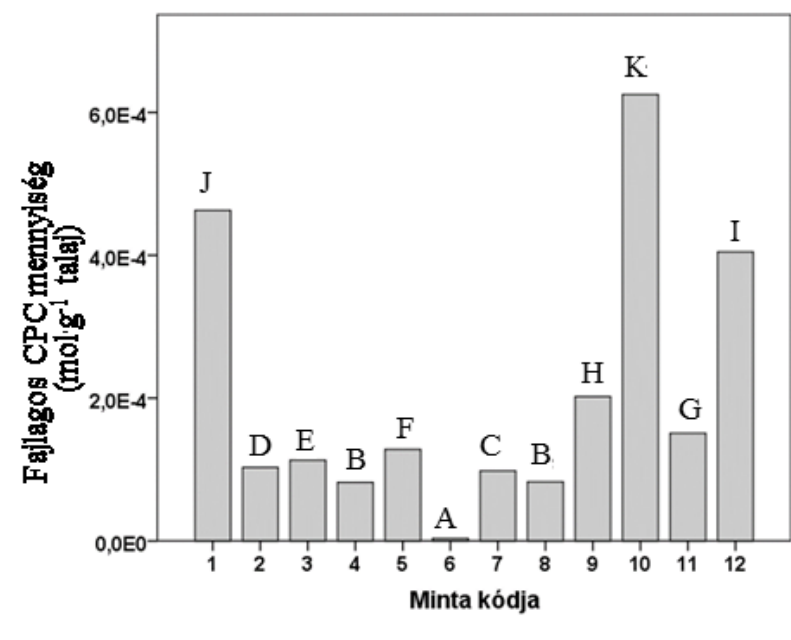

4. ábra

A monomolekuláris rétegborítottság eléréséhez szükséges fajlagos CPC-mennyiségek összehasonlítása.

(Az eltérő betűk a szignifikánsan különböző értékeket jelölik, Dunett T3 próba) 
4. táblázat

A megkötött tenzidmennyiségek és a talajtulajdonságok közötti kapcsolat vizsgálata

\begin{tabular}{|c|c|c|c|c|c|c|c|c|}
\hline & $\begin{array}{c}\text { (1) } \\
\text { Fajl. } \\
\text { CPC, } \\
\text { mol'g } \\
\text { talaj }^{-1}\end{array}$ & $\begin{array}{c}(2) \\
\text { Agyag + } \\
\text { Fe, \% }\end{array}$ & $\begin{array}{c}(3) \\
\mathrm{pH} \\
\left(\mathrm{H}_{2} \mathrm{O}\right)\end{array}$ & $\begin{array}{c}(4) \\
\text { Humusz, } \\
\%\end{array}$ & $\begin{array}{c}(5) \\
\mathrm{CaCO}_{3}, \\
\%\end{array}$ & $\begin{array}{c}(6) \\
\text { BET- } \\
\text { felület, } \\
\mathrm{m}^{2} \mathrm{~g}^{-1}\end{array}$ & $\begin{array}{l}(7) \\
\text { T-érték, } \\
\text { mgeé- } \\
100 \mathrm{~g}^{-1}\end{array}$ & $\begin{array}{l}(8) \\
\text { hy }\end{array}$ \\
\hline $\begin{array}{l}\text { Fajl. CPC, } \\
\text { mol' g talaj }^{-1}\end{array}$ & 1 & & & & & & & \\
\hline Agyag $+\mathrm{Fe}, \%$ & $0,856^{* *}$ & 1 & & & & & & \\
\hline $\mathrm{pH}\left(\mathrm{H}_{2} \mathrm{O}\right)$ & $0,498 * *$ & $0,413^{*}$ & 1 & & & & & \\
\hline Humusz, \% & 0,194 & 0,089 & $-0,178$ & 1 & & & & \\
\hline $\mathrm{CaCO}_{3}(\%)$ & $-0,17$ & $-0,239$ & 0,299 & 0,078 & 1 & & & \\
\hline $\begin{array}{l}\text { BET-felület, } \\
\mathrm{m}^{2} \mathrm{~g}^{-1}\end{array}$ & $0,899 * *$ & $0,902 * *$ & 0,206 & 0,155 & $-0,239$ & 1 & & \\
\hline $\begin{array}{l}\text { T-érték, } \\
\text { mgeé· } 100 \mathrm{~g}^{-1}\end{array}$ & $0,888 * *$ & $0,791^{* *}$ & $0,347^{*}$ & $0,503 * *$ & 0,096 & $0,841 * *$ & 1 & \\
\hline $\mathrm{hy}_{1}$ & $0,929 * *$ & $0,834^{* *}$ & 0,233 & $0,376^{*}$ & $-0,177$ & $0,957 * *$ & $0,917 * *$ & 1 \\
\hline
\end{tabular}

Megjegyzés: a korreláció szignifikáns: $a * 0,05$, illetve **0,01 szinten.

A táblázatot elemezve megállapítható, hogy a fajlagosan adszorbeált tenzidmennyiség erős sztochasztikus kapcsolatban áll az agyagtartalommal, a BET fajlagos felülettel, az összes kicserélhető kation mennyiségével (T-érték) és a (szintén monomolekulárisnak tekinthetö) adszorbeált vízgőz mennyiségével (hy ${ }_{1}$ ). Gyengébb, de még szignifikáns kapcsolatot mutat továbbá a talajok kémhatásával (desztillált vizes $\mathrm{pH}$ ).

A monomolekuláris rétegborítottság eléréséhez szükséges tenzid mennyisége és a talajok humusztartalma közti pozitív korreláció statisztikailag nem igazolható. Hasonlóan nem igazolható a karbonáttartalommal mutatott gyenge negatív korreláció sem. Ezek a talajtulajdonságok - mint a későbbiekben bemutatjuk - a többi tulajdonsággal együtt, komplex módon befolyásolják a tenzidadszorpciót.

A monomolekuláris rétegborítottság kialakításához szükséges tenzidmennyiséget meghatározó talajtulajdonságok hatását leíró többváltozós lineáris regressziós kapcsolatokat az 5. táblázatban mutatjuk be.

A tenzidadszorpcióra gyakorolt hatás szempontjából erős kapcsolatot jelez az agyagtartalom, a BET-felület, a humusztartalom, a kémhatás és a mésztartalom.

\section{5. táblázat}

A CPC adszorpciót leíró regressziós egyenletek

\begin{tabular}{|c|c|c|c|}
\hline Ssz. & Regressziós egyenlet & $\mathrm{R}^{2}$ & $\mathrm{~N}$ \\
\hline 1. & $\mathrm{y}=7,32 \mathrm{E}-06 *$ agyag $\%+2,69 \mathrm{E}-05 *$ humusz $\%+3,91 \mathrm{E}-05 * \mathrm{pH}\left(\mathrm{H}_{2} \mathrm{O}\right)$ & 0,78 & 36 \\
2. & $\mathrm{y}=9,15 \mathrm{E}-06 * \mathrm{BET}+2,55 \mathrm{E}-05 *$ humusz $\%+7,29 \mathrm{E}-05 * \mathrm{pH}\left(\mathrm{H}_{2} \mathrm{O}\right)-$ & 0,94 & 36 \\
$2,78 \mathrm{E}-06 * \mathrm{CaCO}_{3} \%-0,001$ & & \\
\hline
\end{tabular}


Vizsgáltuk az ásványtani tulajdonságok és a monomolekulárisan megkötött tenzid mennyisége közötti korrelációt. Az 5. ábrán bemutatjuk az adszorbeált felületaktív anyag mennyiségét a tenzid-adszorpcióval legszorosabb összefüggést mutató paraméterek függvényében, agyagásvány csoportonként jelölve az összetartozó értékpárokat. A kaolint itt önállóan ábrázoltuk.

Az adszorpciós eredményeket az adszorbens talajtulajdonságokkal összehasonlítva megállapítottuk, hogy a CPC adszorpciójában nagy szerepe lehet ugyan a duzzadó agyagásvány-tartalomnak, de ezt a hatást számos egyéb körülmény módosíthatja. A szmektites minták (1., 10. és 12.) CPC adszorpciója a legnagyobb, amely összefügg azzal is, hogy ezek a minták tartalmazzák a legnagyobb arányú agyagfrakciót. A nagy agyagtartalomhoz képest kiugróan nagy a bentonit (10.) tenzidadszorpciója (a duzzadó agyagásványok mennyisége: $~ 30 \%$ ). Az adszorbeált tenzid mennyisége és a duzzadó agyagásvány-tartalom közötti kapcsolat SALLOUM és munkatársai (2000) tapasztalatai szerint lineáris.
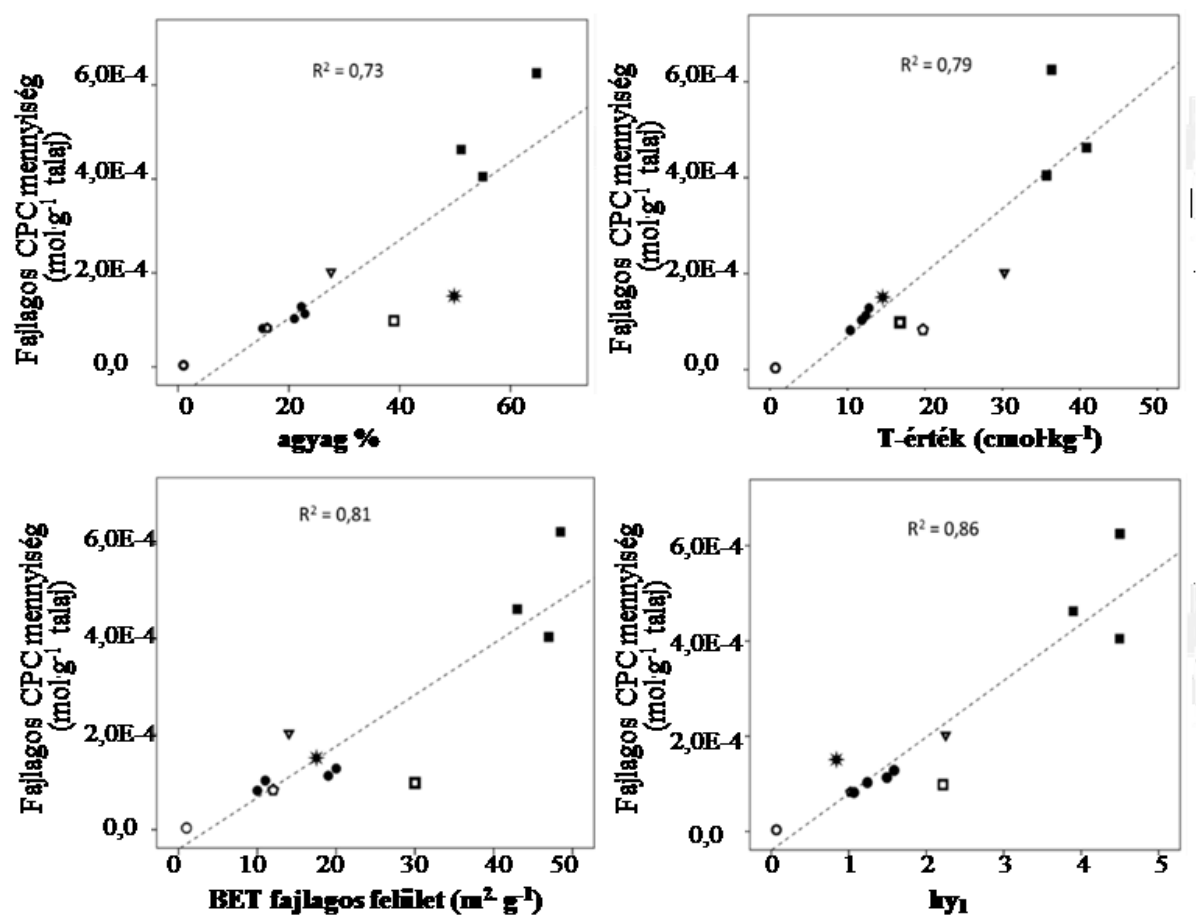

szmekties minták $(1,10,12) \quad \square$ vermiknilitos mintrik (7) $\quad$ szmektitesfilites minták (8)

Villites/kkoritos minták (9) kloritos/vermikmlitos mintrik $(2,3,4,5)$

akrolin (11) Okrarc (6)

5. ábra

A monomolekuláris rétegborítottság eléréséhez szükséges fajlagos CPC mennyiségek összefüggése az ásványtani sajátosságokkal és néhány talajtulajdonsággal 
Az összes talajalkotó ásvány mennyiségéhez képest lényegesen kevesebb ( 4\%) szmektitet tartalmazó karcagi (1.) és kisújszállási (12.) minták tenzidadszorpciója közti különbség - a karcagi réti szolonyec talajminta javára - a felületek töltésviszonyainak különbségével magyarázható (a két talaj T-értéke: 41 és 36 mgeé·100 $\left.\mathrm{g}^{-1}\right)$.

Az ugyancsak duzzadó agyagásványt, vermikulitot tartalmazó ( $\sim 5 \%)$ 7. talajminta az agyagtartalmához képest is nagyon kevés tenzidet adszorbeált. Elképzelhető, hogy ennél a mintánál is bekövetkezett valamilyen kisebb mértékü duzzadás, rácsközi adszorpció, ám a külső és belső felületek nagy részét lefedték a talajmintára jellemző goethit és egyéb vasoxid-hidroxid bevonatok. A még szintén $\sim 5 \%$ duzzadó agyagásványt (szmektitet) tartalmazó paksi lösz (8.) esetében nem tapasztaltunk az agyagtartalom alapján becsülhetőhöz képest kiugró tenzidadszorpciós értékeket. Ennek összetett oka lehet.

A megnövekedett tenzidadszorpciót indokolná ugyan a külső és belső felületeken jelenlévő viszonylag nagyszámú negatív töltés ( $\mathrm{T}$-érték: $20 \mathrm{mgeé} \cdot 100 \mathrm{~g}^{-1}$ ), ám ennek hatását ellensúlyozza (csökkenti) a többi mintáétól eltérően nagy kalcit- és dolomit-tartalom, ezzel összefüggésben a szmektit $\mathrm{Ca}^{2+}$ telítettsége és a mintában kisebb mennyiségben megjelenő goethit. Hasonló eredményeket kaptak MA és munkatársai (2013) is.

A duzzadó agyagásványokat tartalmazó mintákról megállapítható továbbá, hogy - a bentonit (10.) kivételével - olyan kicsi a duzzadó agyagásvány-tartalmuk, hogy annak hatását jórészt elfedik az agyagtartalombeli különbözőségek. Ezért lehet az, hogy a külső felületek hatását leíró (BET), a poláros külső és belső felületek hatását leíró $\left(h_{1}\right)$ és az agyagtartalom hatását leíró regressziós egyenesekhez képest hasonlóan helyezkednek el a minták mért tenzidadszorpció értékei.

A duzzadó agyagásványokat nem, vagy csak igen kismértékben tartalmazó 2 , 3., 4. és 5. talajminták CPC adszorpciója jó összefüggést mutat mind az agyagfrakció mennyiségével, mind a T-értékkel, mind pedig a nitrogén és vízgőzadszorpcióval.

SÁNCHEZ-MARTíN és munkatársai (2008) nem találtak lineáris összefüggést a megkötött kationos felületaktív anyag mennyisége és a T-érték között.

A tenzidadszorpció jórészt a külső agyagásvány felületek negatív töltéshelyein történik. Ezt igen kis mértékben módosítja csak a minták szervesanyag-tartalma. A nagy szervesanyag-tartalmú (3,7\%), duzzadó agyagásványokat nem tartalmazó csernozjom minta (9.) tenzidadszorpciója azonban némiképp eltérő bélyegeket mutat.

A megkötődött CPC mennyisége az agyagtartalom alapján becsülhető értéknél kis mértékben, a BET-felület alapján becsülhetötöl nagyobb mértékben eltér (nagyobb). Ebböl arra következtethetünk, hogy a minta szervesanyag-tartalma is részt vesz a CPC adszorpcióban. Ugyanakkor a talaj T-értéke alapján lényegesen nagyobb tenzidadszorpciót várnánk. Az agyagtartalomhoz képest mért nagy negatív töltés ( $\sim 30$ mgeé $\left.100 \mathrm{~g}^{-1}\right)$ egyértelmüen a csernozjom minta nagy humusztartalmával magyarázható. A humuszanyagoknak azonban - a szakirodalmi adatokkal egybevágóan (pl. KRISHNA MURTI et al., 1966; KUHNT, 1993) - csupán az organominerális komplexumokba be nem épülő része növeli a CPC adszorpciót. 
Az agyagásvány felületekhez kapcsolódó humuszanyag molekulák lefedik a negatív töltéshelyeket, a CPC konkurenseiként viselkednek. Ennél a mintánál a vízgőz-adszorpciós $\left(h_{1}\right)$ értékek ugyanakkor jól követik a CPC adszorpciót - feltehetően hasonló a humuszanyagok hatása a vízgőzadszorpcióra is, mint a tenzidadszorpcióra.

A kaolin minta (11.) CPC adszorpciója a vizsgálatok tanúsága szerint a negatív külső felületeken következik be. Értéke jól becsülhető mind a BET-felület, mind pedig a T-érték alapján. Ugyanakkor nagy az eltérés az agyagtartalom alapján becsülhető és a mért tenzidadszorpció között, melynek oka elsősorban a minta zömét alkotó kaolinit ásvány többi agyagásványhoz viszonyított igen kicsi $\left(\sim 18 \mathrm{~m}^{2} \cdot \mathrm{g}\right)$ fajlagos felülete és kis ( 15 mgeé $\left.100 \mathrm{~g}^{-1}\right)$ T-értéke (XU \& BOYD, 1995; SALlouM et al., 2000). A kvarchomok (6.) a regressziós egyenesek viszonyítási pontjának tekinthető (az agyagfrakciót nem tartalmazó kvarc a kis felületen, minimális negatív töltés mellett elhanyagolhatóan kis mennyiségü tenzid adszorpciójára képes).

\section{Összefoglalás}

Kationos felületaktív anyag, a hexadecilpiridinium-klorid (CPC) adszorpcióját vizsgáltuk különböző talajokon, üledékeken és ásványi őrleményeken. Valódi talajokon történő adszorbeálódásáról kevés irodalmi adat található. Célunk volt meghatározni, hogy mely talajtulajdonságok befolyásolják leginkább a tenzid megkötődését.

A minták ásványos összetételének meghatározása röntgen-pordiffrakcióval (XRD) történt. Ez alapján hat csoportra tudtuk elkülöníteni: 1. Szmektites (kis rétegtöltésủ montmorillonitos) talajok; 2. Vermikulitos talajok; 3. Szmektitet is tartalmazó illites minták; 4. Klorit/vermikulit tartalmú talajok; 5. Illit és klorit tartalmú talajok; 6. Nagy kvarctartalmú minták.

A minták felületaktív anyaggal történő kezelése az ún. „elárasztásos módszerrel” (static equilibrium experiments) valósult meg.

A CPC oldat koncentrációjának függvényében ábrázoltuk a minták által adszorbeált tenzidmennyiségét, majd a mérési pontokra Langmuir-típusú izotermát illesztettünk. Az adszorpciós izotermák segítségével meghatároztuk a vizsgált adszorbensek hidrofóbizálásához szükséges fajlagos tenzidmennyiségeket, amely mellett feltételeztük, hogy a talajszemcsék felületén monomolekuláris tenzidborítottság alakul ki. Az illesztett görbe telítődő jelleget mutat és első szakasza nagy affinitású H-típusra utal. Logaritmikus skálán ábrázoltuk a tenzidadszorpciós értékeket és megállapítottuk, hogy az egyes minták monomolekuláris rétegborítottságához szükséges tenzidmennyiségek mintánként általában szignifikánsan eltérőek. A fajlagos CPC mennyiségét a nagy agyagtartalmú, szmektites minták esetében találtuk a legnagyobbnak, a kvarchomok mintáét pedig a legkisebbnek.

Vizsgáltuk, hogy a minták mely tulajdonságai állnak kapcsolatban a monomolekuláris telítettségnél adszorbeált fajlagos tenzid mennyiségekkel. Számítottuk továbbá a Pearson-féle korrelációs együtthatókat. 
A fajlagos tenzid mennyiségével szoros összefüggést mutatott a higroszkóposság (hy $)_{1}$, az agyagtartalom, a fajlagos felület (BET-felület) és a kationcserélő képesség (T-érték). A CPC adszorpcióját leíró regressziós egyenletek szerint öt paraméter határozza meg a fajlagos tenzid mennyiségét: agyag-, humusz-, mésztartalom, $\mathrm{pH}\left(\mathrm{H}_{2} \mathrm{O}\right)$ és a BET-felület.

Kulcsszavak: kationos felületaktív anyag, talaj, adszorpció, izoterma, agyagásvány

TÁMOP-4.2.1/B-09/1/KONV-2010-0003 Mobilitás és környezet: Jármüipari, energetikai és környezeti kutatások a Közép- és Nyugat-Dunántúli Régióban. A projekt a Magyar Állam és az Európai Unió támogatásával, az Európai Szociális Alap társfinanszírozásával valósult meg.

\section{Irodalom}

Abu-ZReig, M., RudRa, R. P. \& Dickinson, W. T., 2003. Effect of application of surfactants on hydraulic properties of soils. Biosystems Engineering. 84. (3) 363-372.

Allred, B. \& BROwN, G. O., 1994. Surfactant induced reduction in soil hydraulic conductivity. Ground Water Monitoring and Remediation. 14. 174-184.

ARINGHIERI, R. \& SEQUI, P., 1978. The arrangement of organic matter in a soil crumb. In: Modification of Soil Structure (Eds.: EMERSON, W. W., Bond, R. D. \&. DeXTER, A. R.) 145-150. John Wiley. New York.

Atkin, R., Craig, V. S. J., Wanless, E. J. \& BigGs, S., 2003. Mechanism of cationic surfactant adsorption at the solid-aqueous interface. Advances in Colloid and Interface Science. 103. 219-304.

BaE, S., Mannan, M. B. \& LeE, W., 2012. Adsorption of cationic cetylpyridinium chloride on pyrite surface. Journal of Industrial and Engineering Chemistry. 18. 14821488.

Banks, M. L., Kennedy, A. C., Kremer, R. J. \& Eivazi. F., 2014. Soil microbial community response to surfactants and herbicides in two soils. Applied Soil Ecology. 74. $12-20$.

BROwN, M. J. \& BURRIS, D. R., 1996. Enhanced organic contaminant sorption on soil treated with cationic surfactants. Ground water. 34. 734-745.

Brunauer, S., Emmett, P. H. \& Teller, E., 1938. Adsorption of gases in multimolecular layers. Journal of the American Chemical Society. 60. 2 309-319.

BURFord, J. R., DeshPANDE, T. L., GREENLAND, D. J. \& QuirK, J. P., 1964. Influence of organic materials on the determination of the specific surface areas of soils. Journal of Soil Science. 15. 192-201.

Csatári T., Makó A., Skic, K., Tóth Z. \& Balázs R., 2013. A talajok víz- és szervesfolyadék-visszatartó képességének változása kationos felületaktív anyaggal történő kezelés hatására. In: Talajvédelem Különszám. Talajtani Vándorgyülés, Miskolc, 2012. aug. 23-25. (Szerk.: Dobos E., Bertóti R. D. \& SzABÓNÉ Kele G.) 105-114. Könyvmühely - Z-Press Kiadó. Miskolc. 
Dobozy, O., LakATos, M. \& MÁTÉ, F., 1970. Vlijanyije nyekotorih povernosztnoaktivnih $\mathrm{u}$ drugih organicseszkih vescsesztv na fizicsekie szvojsztva pocsvi i razvityije rasztyenyii. Zsurnal Prikladnoj Himii. XLIII. 639-645.

Fan, A., Somasundaran, P. \& Turro, N. J., 1997. Adsorption of alkyltrimethylammonium bromides on negatively charged alumina. Langmuir. 13. 506-510.

FÖldÉNYi R., TóTH Z., CSATÁRI T. \& MAKÓ A., 2013. Egy kationos tenzid (CPC) adszorpciója talajokon és talajalkotókon. Talajvédelem Különszám. In: Talajvédelem Különszám. Talajtani Vándorgyülés, Miskolc, 2012. aug. 23-25. (Szerk.: DoBOS E., Bertóti R. D. \& SzABÓNÉ Kele G.) 181-187. Könyvműhely - Z-Press Kiadó. Miskolc.

GaO, B., Wang, X., ZhaO, J. \& Sheng, G., 2001. Sorption and cosorption of organic contaminant on surfactant-modified soils. Chemosphere. 43. 1095-1102.

Giles, C. H., Macewan, T. H., NAKhva, S. N. \& Smith, D., 1960. Studies in adsorption. Part XI. A system of classification of solution adsorption isotherms, and its use in diagnosis of adsorption mechanisms and in measurement of specific surface areas of solids. Journal of the Chemical Society. 1960. 3973-3993.

GreEnland, D. J. \& QUIRK, J. P., 1964. Determination of the total specific surface areas of soils by adsorption of cetyl pyridinium bromide. Journal of Soil Science. 15. 178-191.

Hrenovic, J., Ivankovic, T., Sekovanic, L. \& Rozic, M., 2008. Toxicity of dodecylpyridinium and cetylpyridinium chlorides against phosphate-accumulating bacterium. Central European Journal of Biology. 3. 143-148.

Karagunduz, A., Pennel, K. D. \& Young, M. H., 2001. Influence of a nonionic surfactant on the water retention properties of unsaturated soils. Soil Science Society of America Journal. 65. 1392-1399.

Krishna MurTi, G. S. R., VolK, V. \& JACKSON, M. L., 1966. Soil adsorption of Linear Alkylate Sulfonate. Soil Science Society of America Proceeding. 30. 685-688.

KuHNT, G., 1993. Behaviour and fate of surfactant in soil. Environmental Toxicology and Chemistry. 12. 1813-1820.

Lakra, J., Tikariha, D., Yadav, T., SATnAmi, M. L. \& GHOSh, K. K., 2013. Study of solubility efficiency of polycyclic aromatic hydrocarbons in single surfactant systems. Journal of Surfactants and Detergents. 16. 957-966

LAW, J. P. JR. \& KUNZE, G. W., 1966. Reactions of surfactants with montmorillonite: Adsorption mechanisms. Soil Science Society of America Proceeding. 30. 321326.

LAW, J. P. JR., Bloodworth, M. E. \& Runkles, J. R., 1966. Reactions of surfactants with montmorillonitic soils. Soil Science Society of America Proceeding. 30. 327 332.

Lowe, D. F., OuBre, C. L. \& WARD, C. H., 1999. Reuse of surfactants and cosolvents for NAPL remediation. A technology practices manual. Lewis Publishers, Boca Raton.

Ma, K., Cui, L., Dong, Y., Wang, T., Da, C., Hirasaki, G. J. \& Biswal, S. L., 2013. Adsorption of cationic and anionic surfactants on natural and synthetic carbonate materials. Journal of Colloid and Interface Science. 408. 164-172.

Malik, W. U., Srivastava, S. K. \& Gupta, D., 1972. Studies on the interaction of cationic surfactants with clay minerals. Clay Minerals. 9. 369-382. 
MAYER, L. M. \& Rossi, P. M., 1982. Specific surface areas in coastal sediments: Relationships with other textural factors. Marine Geology. 45. 241-252.

Miókovics, E., SzÉPlÁBI, G., Makó, A., Hernádi, H. \& Hermann, T., 2011. Effects of surfactants on the aggregate stability of soils. Hungarian Journal of Industrial Chemistry, Veszprém. 39. 1 127-131.

Mulligan, C. N., Yong, R. N. \& GiBBS, B. F., 2001. Surfactant-enhanced remediation of contaminated soil: a review. Engineering Geology. 60. 371-380.

PARIA, S., 2008. Surfactant-enhanced remediation of organic contaminated soil and water. Andvances in Colloid and Interface Science. 123. 24-58.

PATZKó Á., 1998. A kolloidika alapjai. József Attila Tudományegyetem. Szeged.

PATZKÓ Á. \& DÉKÁNY I., 1996. Talaj-tenzid kölcsönhatás, adszorpció, nedvesedés és az üledék vízáteresztő képességének változása. Agrokémia és Talajtan. 45. 229-237.

Piccolo, A. \& MBAGWU, J. S. C., 1989. Effects of humic substances and surfactants on the stability of soil aggregates. Soil Science. 147. (1) 47-54.

RaO, P-H. He, M., YANG, X., Zhang, Y-C., Sun, S-Q. \& WANG, J-S., 2006. Effect of an anionic surfactant on hydraulic conductivities of Sodium- and Calcium-saturated soils. Pedosphere. 16. (5) 673-680.

RASHID, T., AKBER, A. \& AL-AwADI, E., 2004. Use of surfactants in enhancing the sorption of petroleum hydrocarbons by natural aquifer materials: a laboratory study. Emigrates Journal for Engineering Research. 9. 29-34.

Ratherfelder, K., Abriola, L. M., Singletary, M. A. \& Pennell, K. D., 2003. Influence of surfactant-facilitated interfacial tension reduction on chlorinated solvent migration in porous media: observations and numerical simulation. Journal of Contaminant Hydrology. 64. 227-252.

SABAtini, D. A., KNOX, R. C. \& Harwell, J. H., 1996. Surfactant-enhanced DNAPL remediation: Surfactant selection, hydraulic efficiency, and economic factors. US EPA. EPA/600/S-96/002.

Salloum, M., Dudas, M. J., McGill, W. B. \& Murphy, S. M., 2000. Surfactant sorption to soil and geological samples with varying mineralogical and chemical properties. Environmental Toxicology and Chemistry. 19. 2436-2442.

Sánchez-Martín, M. J., Dorado, M. C., Del Hoyo, C. \& Rodríguez-Cruz, M. S., 2008. Influence of clay mineral structure and surfactant nature on the adsorption capacity of surfactants by clays. Journal of Hazardous Materials. 150. 115-123.

SHENG, G., XU, S. \& BoYD, S. A., 1996. Cosorption of organic contaminant from water by hexadecyltrimethyilammonium-exchanged clays. Water Resource. 30. (6) 1483-1489.

Slade, P. G., RAupach, M. \& EMERSON, W. W., 1978. The ordering of cetylpyridinium bromide on vermiculite. Clays and Clay Minerals. 26. (2) 125- 134.

TyURIN, I. V., 1931. A new modification of the volumetric method of determining soil 344 organic matter by means of chromic acid. Pochvovedenie. 5-6. 36-47.

WEST, C. C. \& HARWELL, H., 1992. Surfactants and surface remediation. Environmental Science and Technology. 26. (12) 2324-2330.

XU, S. \& BoYD, S. A., 1995. Cationic surfactant adsorption by swelling and nonswelling layer silicates. Langmuir. 11. 2508-2514.

Érkezett: 2015. március 2. 


\title{
Adsorption of cationic surfactant (hexadecylpyridinium chloride monohydrate) on soil
}

\author{
${ }^{1}$ Gy. BARNA,${ }^{2}$ R. FÖLDÉNYI, ${ }^{2} Z$. TÓTH, ${ }^{3}$ R. BALÁZS and ${ }^{1}$ A. MAKÓ
}

\begin{abstract}
${ }^{1}$ Institute for Soil Science and Agricultural Chemistry of the Hungarian Academy of Sciences, Budapest, ${ }^{2}$ Department of Earth and Environmental Sciences, Faculty of Engineering, University of Pannonia, Veszprém, ${ }^{3}$ MTA Research Center for Astronomy and Earth Sciences, Budapest
\end{abstract}

\section{Summary}

Studies were made on the adsorption of a cationic surfactant, hexadecylpyridiniumchloride (CPC), on various soils, sediments and minerals. Very few data are available in the literature on the CPC adsorption on real soil. The aim was to determine which soil characteristics have the greatest influence on surfactant adsorption.

The mineral composition of the samples was measured by X-ray diffractometry, which revealed six groups based on the dominant mineral: 1: Smectite soils (soils with low- charged montmorillonite); 2. Vermiculite soils; 3 . Illite soils also containing smectite; 4. Soils containing chlorite/vermiculite; 5 . Illite- and chlorite-containing soils; 6 . Soils with high quartz content.

The samples were treated with surfactant in the course of static equilibrium experiments. The quantity of surfactant adsorbed by the samples was plotted as a function of the concentration of the CPC solution, after which Langmuir isotherms were fitted to the measurement points. The specific quantity of surfactant required to make the adsorbents hydrophobic was determined based on the adsorption isotherms, assuming that a monomolecular surfactant layer was formed on the surface of the soil particles. The fitted curves were of the saturation type, the first section of which was characteristic of high affinity (H-type) isotherms. Later, logarithmic plotting was employed, and the analysis of the surfactant adsorption values thus obtained showed that the surfactant quantities needed to form a monomolecular layer differed significantly for the individual samples. The specific CPC quantity was highest for the smectite samples, which have high clay content, and lowest for the quartz sand.

Pearson's correlation coefficients were calculated to determine which characteristics of the samples were correlated with the specific CPC quantities. Strong stochastic relationships were detected with the cation exchange capacity (CEC) and with the adsorbed water vapour $\left(\mathrm{hy}_{1}\right)$, which can also be considered as monomolecular. A weaker but significant correlation was found with the soil $\mathrm{pH}\left(\mathrm{H}_{2} \mathrm{O}\right)$. After backward elimination, the regression equations found to describe $\mathrm{CPC}$ adsorption involved the clay content, BET specific surface area, humus content, carbonate content and $\mathrm{pH}\left(\mathrm{H}_{2} \mathrm{O}\right)$.

Table 1. Major physical and chemical characteristics of the soil samples. (1) Sample code. (2) Upper limit of plasticity according to Arany. (3) Hygroscopicity. (4) Clay+Fe, \%. (5) Silt, \%. (6) Sand, \%. (7) Humus, \%. (8) CEC, meq $100 \mathrm{~g}^{-1}$. (9) Specific surface area, $\mathrm{m}^{2} \cdot \mathrm{g}^{-1}$.

Table 2. Major properties of hexadecyl-pyridinium chloride monohydrate. (1) Properties. (2) Value. (3) Empirical formula. a) Molecular formula; b) Molecular mass, 
$\mathrm{g} \cdot \mathrm{mol}^{-1}$; c) Water solubility, $\mathrm{g} \cdot \mathrm{cm}^{-3}$; d) Density, $\mathrm{g} \cdot \mathrm{cm}^{-3}$; e) $\mathrm{pH}$ (at concentration: 10 $\left.\mathrm{g} \cdot \mathrm{dm}^{-3}\right)$.

Table 3. Mineral content of the samples, \%. (1) Sample code. (2) Swelling clay minerals. (3) Illite/mica. (4) Chlorite/kaolinite. (5) Quartz. (6) K-feldspar. (7) Plagioclase. (8) Calcite. (9) Dolomite. (10) Goethite.

Table 4. Correlation matrix for the relationship between adsorbed surfactant quantities and soil parameters. (1) Specific CPC, mol $\mathrm{g}^{-1}$ soil. (2) Clay+Fe, \%. (3) $\mathrm{pH}\left(\mathrm{H}_{2} \mathrm{O}\right)$. (4) Humus, \%. (5) BET specific surface area, $\mathrm{m} \cdot \mathrm{g}^{-1}$. (6) CEC, meq $100 \mathrm{~g}^{-1}$. (7) hy $\mathrm{h}_{1}$ Notes: $*$ and $* *$ correlation is significant at the 0,05 and 0,01 level.

Table 5. Regression equations describing CPC adsorption.

Figure 1. Measuring points for CPC adsorption in meadow soil.

Figure 2. Determination of monomolecular CPC layer in meadow soil.

Figure 3. Oriented adsorption of ionic surfactants (according to FAN et al., 1997).

Figure 4. Comparison of specific CPC quantities required to form a monomolecular layer. (Different letters indicate significantly different values.)

Figure 5. Correlation between the specific CPC quantities required to form a monomolecular layer and various mineralogical and soil parameters. y-axis: specific $\mathrm{CPC}$ quantity, $\mathrm{mol} \cdot \mathrm{g}^{-1}$ soil; $\mathrm{x}$-axis: clay $\%$; CEC, $\mathrm{cmol} \cdot \mathrm{kg}^{-1}$; BET specific surface area, $\mathrm{m}^{2} \cdot \mathrm{g}^{-1} ; \mathrm{hy}_{1}$. 